\title{
Undergraduate Research as a High Impact Practice in Higher Education
}

\author{
Shari Lanning ${ }^{1}$ and Mark Brown ${ }^{1,2,3,4,5, *}$ \\ Education Section, Department of Clinical Sciences, Colorado State University, Fort Collins, CO 80523, USA \\ Institute for Learning and Teaching, Colorado State University, Fort Collins, CO 80523, USA \\ Department of Ethnic Studies, Colorado State University, Fort Collins, CO 80523, USA \\ 4 Epidemiology Section, Colorado School of Public Health, Colorado State University Fort Collins, CO 80523, \\ USA \\ 5 Cell and Molecular Biology Program, Colorado State University, Fort Collins, CO 80523, USA \\ * Correspondence: Mark.Brown@colostate.edu; Tel.: +1-970-491-5782
}

Received: 18 June 2019; Accepted: 19 June 2019; Published: 26 June 2019

\begin{abstract}
Higher education research indicates that student engagement is the most critical factor in retention programs for undergraduate students (Upcraft, Gardner and Barefoot, 2005; Tinto, 2012; Pascarella, Seifert, and Whitt, 2008). These studies illustrate that if students do not feel engaged, they are at high risk for leaving their institution prematurely. Among high impact practices, undergraduate research has been shown to have the most positive effects with regard to promoting student engagement (Kuh, 2018; Kuh, 2008). Herein we highlight the use of mentored research as a high impact practice in undergraduate education, Further, we call upon the education community to share their models, approaches, observations, and research findings related to undergraduate research initiatives.
\end{abstract}

Keywords: undergraduate research; student engagement; higher education; high impact practices

\section{Introduction}

Student engagement has been repeatedly underscored as an essential element in undergraduate retention initiatives [1-3]. Specifically, if students do not feel engaged, there is a greater chance that they may precipitately leave their institution. Mentored research is considered to be a high impact practice and imparts the most positive outcomes among such practices that emphasize the engagement of undergraduates $[4,5]$.

\section{Discussion}

Undergraduate research provides students with practical problem-solving skills [6-8]. The interplay between theory, provided through formal training in the classroom, and practice, offered through mentored research experiences, enhances both student learning and students' early definition of career goals [6]. With undergraduate research, the students' direct exposure and response to real-world problems and reflection upon the outcomes of their actions serve as means for the development and evolution of knowledge related to their subjects of interest [9]. Undergraduate research is particularly suitable for bridging difficult subjects across multiple disciplines $[9,10]$. The importance of faculty mentor contact for students, within a context of active student engagement through tasks that require strategies such as research, is being increasingly emphasized in models for student engagement and retention [2]. Thus, we call upon the community of higher education researchers to share their views, experiences, and findings related to undergraduate research in this 
Special Issue of Education Sciences titled, "Undergraduate Research as a High Impact Practice in Higher Education." For information on this Special Issue, visit:

https://www.mdpi.com/journal/education/special_issues/Undergraduate_Research

Author Contributions: S.L. and M.B. wrote the paper. Both authors read and approved the final manuscript.

Conflicts of Interest: The authors declare no conflicts of interest. Brown is a Guest Editor for the Special Issue of Education Sciences, "Undergraduate Research as a High Impact Practice in Higher Education" highlighted in this article and receives no remuneration for this work.

\section{References}

1. Upcraft, M.; Gardner, J.; Barefoot, D. (Eds.) Challenge and Support: Creating Climates for First Year Student Success; Jossey-Bass: San Francisco, NC, USA, 2005.

2. Tinto, V. Completing College: Rethinking Institutional Action; The University of Chicago Press: Chicago, IL, USA, 2012.

3. Pascarella, E.T.; Seifert, T.A.; Whitt, E.J. Effective instruction and college student persistence: Some new evidence. New Dir. Teach. Learn. 2008, 55-70.

4. Kuh, G.D. What Really Makes a 'High-Impact' Practice High Impact? Inside Higher Education, 1 May 2018.

5. Kuh, G.D. Student Success in College: The Promise of High Impact Practices; Association of American Colleges and Universities: Washington, DC, USA, 2008.

6. Boyd, M.K.; Wesemann, J.L. Broadening Participation in Undergraduate Research: Fostering Excellence and Enhancing the Impact; Council on Undergraduate Research: Washington, DC, USA, 2009.

7. Kardash, C.M. Evaluation of an undergraduate research experience: Perceptions of undergraduate interns and their faculty mentors. J. Educ. Psychol. 2000, 92, 191-201. [CrossRef]

8. National Research Council. Committee on developments in the Science of Learning and Committee on Learning Research and Educational Practice. In How People Learn: Brain, Mind, Experience, and School; expanded ed.; National Academy Press: Washington, DC, USA, 2000.

9. Kuh, G.D.; Kinzie, J.; Schuh, J.H.; Whitt, E.J. Student Success in College: Creating Conditions that Matter; Jossey-Bass: San Francisco, NC, USA, 2005.

10. Itin, C.M. Reasserting the Philosophy of Experiential Education as a Vehicle for Change in the 21st Century. JEE 1999, 22, 91-98. [CrossRef]

(C) 2019 by the authors. Licensee MDPI, Basel, Switzerland. This article is an open access article distributed under the terms and conditions of the Creative Commons Attribution (CC BY) license (http://creativecommons.org/licenses/by/4.0/). 